\title{
The establishment of large private nature reserves by conservation NGOs: key factors for successful implementation
}

\author{
Lorena Pasquini, James A. Fitzsimons, Stuart Cowell \\ KATRINA BRANDON and GEOFF WESCOTT
}

\begin{abstract}
Private nature reserves created by nongovernmental organizations (NGOs) are increasing, and their growing number and extent means that they can potentially contribute to biodiversity goals at a global scale. However, the success of these reserves depends on the legal, economic and institutional conditions framing their creation and management. We explored these conditions, and the opportunities and challenges facing conservation organizations in managing private nature reserves, across several countries, with an emphasis on Australia. Results from 17 semi-structured interviews with representatives of private conservation organizations indicated that while private reserves may enhance the conservation estate, challenges remain. Legal frameworks, especially tenure and economic laws, vary across and within countries, presenting conservation organizations with significant opportunities or constraints to owning and/or managing private nature reserves. Many acquired land without strategic acquisition procedures and secured funding for property acquisition but not management, affecting the long-term maintenance of properties. Other typical problems were tied to the institutional capacity of the organizations. Greater planning within organizations, especially financial planning, is required and NGOs must understand opportunities and constraints present in legislative frameworks at the outset. Organizations must establish their expertise gaps and address them. To this end, partnerships between organizations and/or with government can prove critical.
\end{abstract}

\footnotetext{
LORENA PASQUINI* (Corresponding author) Department of Geography, University of Sheffield, Sheffield, UK. E-mail lorena.pasquini@gmail.com

James A. Fitzsimons ${ }^{\dagger}$ and Geoff Wescott School of Life and Environmental Sciences, Deakin University, Burwood, Victoria, Australia

StuART $_{\text {Cowell }}{ }^{\ddagger}$ Bush Heritage Australia, Lenah Valley, Tasmania, Australia

KATRINA BRANDON Conservation International, Arlington, Virginia, USA

${ }^{\star}$ Current address: Department of Environmental \& Geographical Science, Shell Environmental \& Geographical Science Building, University of Cape Town, Private Bag X3, Rondebosch 7701, South Africa

${ }^{\dagger}$ Current address: The Nature Conservancy, Carlton, Victoria, Australia

‡Current address: Tasmanian Land Conservancy, Lower Sandy Bay, Tasmania, Australia

Received 1 February 2010. Revision requested 15 April 2010.

Accepted 1 July 2010. First published online 7 June 2011.
}

Keywords Conservation covenants, land acquisition, management costs, NGO, private nature reserve

\section{Introduction}

D rivate nature reserves created and managed by nongovernmental conservation organizations and land trusts can complement statutory protected areas, increasing the total area managed for conservation (Campbell \& Salus, 2003; Parker, 2004; Figgis et al., 2005; King \& Fairfax, 2005; Cowell \& Williams, 2006). Globally, efforts to conserve nature through private reserves are gaining momentum in many countries (Carter et al., 2008; Pasquini et al., 2010). In Central America, for example, $>350,000$ ha of land are within private protected areas (Chacon, 2005). While many private reserves are managed by individuals, non-governmental organizations (NGOs) in North America, Australia and Latin America are increasingly creating and managing such reserves (ELI, 2003; Armsworth et al., 2006).

In the USA The Nature Conservancy (TNC) manages c. 6.5 million ha of private land and, up to 2003, a further c. 3.8 million ha were protected by 1,537 smaller NGOs (Armsworth et al., 2006). Private land conservation in Australia has changed rapidly over the last decade, with numerous NGOs at the national scale engaging in private lands conservation (Figgis et al., 2005; Cowell \& Williams, 2006). Major national NGOs purchasing and managing large private nature reserves are Bush Heritage Australia and the Australian Wildlife Conservancy, and Birds Australia has acquired two large properties for conservation. State-based groups are also creating private nature reserves, such as the Trust for Nature in Victoria, a nonprofit organization dedicated to conserving all significant natural areas in private ownership in Victoria by acquiring properties to own outright and as part of a revolving fund (a fund established for a certain purpose, with the stipulation that repayments to the fund may be used anew for the same purpose) and covenanting (Cowell \& Williams, 2006). A number of smaller jurisdictional-based land trusts also operate elsewhere in Australia.

Compared to public sector protected areas, private nature reserves have been cited as having advantages of focus, flexibility, affordability and ability to provide longterm conservation management (Campbell \& Salus, 2003; 
SECITAC, 2007). Conservation NGOs may have greater management flexibility because they can access and use resources donated by charities and philanthropic organizations for conservation objectives unallowable for statutory protected areas (SECITAC, 2007). On the other hand many conservation land trusts have limited staff and budgets, small memberships and few landholdings, and thus comprehensive or coordinated conservation over large areas is limited (Foti \& Jacobs, 1989; Campbell \& Salus, 2003). Although private nature reserves have the potential to contribute significantly to global biodiversity goals, their fate is intricately tied to the success of NGOs and to the legal and policy context for their creation and management.

However, there is little published research on when and how land purchase and management by private conservation organizations work best under differing legal, institutional, political, social and economic settings. Here, we address some of these gaps. Our aims are to initiate debate and stimulate further research by suggesting broad guidelines for establishing and managing private nature reserves. We base our suggestions on lessons learned from an exploratory analysis of the legal, economic and institutional conditions framing three key aspects of the establishment of private nature reserves: (1) land identification, (2) financing for acquisition and management, and (3) ongoing land management. We contrast the opportunities and challenges facing NGOs in establishing and managing sites for biodiversity conservation and conclude by discussing alternative mechanisms to full land acquisition strategies.

\section{Methods}

Our exploratory analysis was focused on Australia but also drew in lessons extracted internationally. During March-May 2007 we conducted in-depth semi-structured interviews comprised of a general series of open-ended questions with 17 representatives from conservation NGOs principally involved in land acquisition in Australia, North America, Central America, South America and Africa. Eleven interviews consisted of face-to-face meetings, five were phone interviews and one respondent supplied written answers via e-mail. Interviews lasted $40-60 \mathrm{mi}-$ nutes. The sample included representatives from the biggest Australian NGOs involved in land acquisition (Bush Heritage Australia, Birds Australia and the Trust for Nature) with the exception of the Australian Wildlife Conservancy (no interview because of scheduling conflicts). The remaining interviews were mostly with representatives from TNC because it is the largest global private lands conservation organization. Each organization identified the most appropriate and experienced person in the acquisition and administration of private nature reserves to be the respondent. The sample had seven TNC practitioners (one in Australia, two in the USA, two in South America, one in Central America and one in Africa), three Bush Heritage Australia practitioners, two Birds Australia practitioners, two Trust for Nature (Victoria) practitioners, one former TNC practitioner with experience in Latin America, Africa and Australia, one representative from the World Commission on Protected Areas (Australia and New Zealand programme), and one board member for the World Land Trust USA and Nature \& Culture International (two land trusts operating in Latin America). These last two respondents both have considerable expertise in private lands conservation and have written extensively on the topic.

Interviews investigated the following broad topics (with a focus on establishment of large private nature reserves in remote regions): (1) The approaches used by NGOs to identify land (e.g. opportunistic vs strategic land identification procedures); (2) How laws and/or legal frameworks affect the processes of land acquisition and management; (3) Funding sources for acquisition and sustainability (long-term management) of private nature reserves; (4) The root causes of the failure of private nature reserves (i.e. when NGOs fail in their original expectation of retaining ownership or sustaining the management of a private nature reserve), including strategies for minimizing this occurrence.

All interviews were taped and transcribed, and coding and analysis of the transcripts were based on methods outlined in Kitchin \& Tate (1999). In-depth qualitative methodologies were employed to seek subjective understanding of social reality, and were suitable for the intended aim of research, that of theoretical generalization. The use of qualitative methodologies allowed respondent attitudes to emerge within the analysis, avoiding the possibility of researcher-directed responses or that respondents would give answers 'preferred' by the researchers. The subjective understanding gained through this research is intended to provide an initial broad awareness of the issues, limitations and opportunities facing the establishment of private nature reserves, to guide the development of future, more systematic research aimed at developing more detailed recommendations. Triangulation of findings was performed by examining the websites and published material of the conservation organizations surveyed.

\section{Results}

\section{Funding constraints to establishment and management}

NGOs can generate the funds required for land acquisition from multiple sources, although the relative importance of each source varied between NGOs and countries. For example, support from locally established donor bases appeared much stronger in more developed countries (the USA and Australia) than in less developed countries 
(Africa and Latin America). In the USA and Australia most funding came from private individuals, followed by institutional grants and corporate donations (see also AWC, 2006; BHA, 2006; TNC, 2006b; Kendall, 2007; SECITAC, 2007). Seven respondents noted that in these countries governments can also play a key role in supporting the acquisition of large properties. Economic laws for the establishment of private nature reserves can also be extremely important (seven respondents). Five respondents specifically identified laws providing income tax exemption for donors or property tax exemption for conservation NGOs as desirable, as highlighted in the following statement by a TNC respondent in the USA:

... having the right legal infrastructure for philanthropy [is very important] ... so that people can donate land to you and it makes financial sense for them to do that, or there's something in it for them, or even [they can] give you a partial donation.

However, finding funding for ongoing management was challenging, as one Latin American respondent explained:

... it's difficult for donors to see the need to pay for management, and especially because you're asking for money for management in perpetuity, not to manage the land for 1 year or 2 years or 3 years.

The general reluctance of donors to fund management requirements appeared to be shared by government in some locations and one USA respondent confirmed that state or federal grants are usually only available for land acquisition. The Latin American representative stressed that 'you need to generate a flow of income that will allow the organization to be there forever'.

Seven respondents felt that this lack of long-term management funding was the principal reason for NGOs failing to maintain and/or retain private nature reserves in the long term. Australian respondents cited two such examples supporting this view: (1) In 2006 Birds Australia reluctantly but voluntarily transferred its Newhaven Station reserve, purchased only 5 years earlier, to the Australian Wildlife Conservancy because of a funding shortfall for ongoing management (see also Russell-French, 2005). (2) Earth Sanctuaries Ltd was the first publicly listed company in Australia to have wildlife conservation as its primary goal (ESL, 2000), owning 11 properties covering c. 100,000 ha at its peak of land ownership. It sought to generate income by placing a monetary value on the threatened species it owned (Sydee \& Beder, 2006). Yet, the company overestimated the revenue-generating potential of its extensive landholdings and suffered financial difficulties and was eventually delisted in 2006. The majority of its reserves were purchased by the Australian Wildlife Conservancy but the demise created a potential loss in confidence in the private nature reserve system in Australia (Fitzsimons \& Wescott, 2002).
Nine respondents felt that NGOs devoted too much attention to funding property acquisition when a more critical problem was funding for ongoing management, as expressed in the following statement by a Latin American respondent:

... the sexiness of buying a property [...] it's such a milestone, it's such an interesting objective, that it's usually very easy to forget about the not-so-attractive requirements in institutional capacity before buying it. It was very, very common to find capital campaigns, or acquisitions campaigns, or just institutions doing an acquisition that would put all their effort into getting the land, so to find themselves after a very big party and public announcement and everything [...] completely deluded and [...] weakened by that effort, when the real work comes, which is actually to manage the land.

Eleven respondents agreed that NGOs need to address ongoing funding for private nature reserve management more carefully, balancing their environmental objectives against their financial viability. While some donors may not appreciate the need for creating an endowment fund for ongoing management, the experience of five respondents suggests that endowment funds are a good tool for maintaining a flow of resources for management in perpetuity. TNC in the USA deals with this issue by raising money for both property acquisition and management concurrently. Seven respondents suggested that sustainable revenuegenerating activities that are compatible with the private nature reserve's conservation objectives could help contribute to management costs, especially if NGOs relied primarily on international grants for their revenue (e.g. Latin America). In some cases a low-intensity controlled version of traditional land uses may be appropriate, especially where land tenure laws require specific land uses. Ecotourism has often been a preferred approach (Gössling, 1999; Aretino et al., 2001; Kruger, 2005; Che, 2006). However, five interviews highlighted that tourism, especially of large remote private nature reserves, is unlikely to generate revenue sufficient to cover the costs of operation (see also Brandon, 1996; Aretino et al., 2001), mainly because larger and more remote sites can require exceptional features to attract visitors. Six interviews revealed that NGOs can also use volunteers to assist with management, and five respondents cited Birds Australia's Gluepot reserve as an example of how an enthusiastic committed community of volunteers could be a major factor in sustainable reserve management.

\section{Role of institutional capacity in success or failure}

Seven respondents linked failure of a private nature reserve to underlying weaknesses in institutional capacity, as this extract indicates:

... most of the cases that fail, most of the experiences that fail, [were due to] the lack of institutional capacity, [to] a weak sponsor, [to] a weak NGO, [to] a weak manager of the land. 
And I think if you don't have money what you have is probably a weak institution, that should be raising the money.

Five respondents explicitly recommended that NGOs should develop 'organizational maturity' through two steps. In the first place, NGOs should recognize their core business (i.e. the organization's main or essential activities) because NGOs were considered to be too idealistic, often failing to consider all aspects of land purchase and management in advance. Eleven respondents called for NGOs to have clear visions of their mission and objectives and better strategic planning. For instance, Bird Australia's representatives suggested that the organization had stepped outside its mission (to promote the conservation, study and enjoyment of Australia's native birds and their habitats) in purchasing land for conservation (see also Russell-French, 2005). Eight respondents highlighted that planning for private nature reserves should include an overall vision for the site that incorporates both conservation and financial goals (a business plan or financial evaluation), including an estimate of the costs of reserve management and the identification of funding sources to cover these costs.

TNC and the Trust for Nature both exemplify NGOs that clearly identify their core business. TNC is increasingly transferring acquired properties to other land trusts or to government departments. The Trust for Nature sells on its acquired properties through a revolving fund (with a covenant attached as a condition of sale). The Trust's representatives also highlighted that covenanting (rather than acquisition) can prove the most sensible option for conservation in amenity landscapes, where landholders are purchasing land for reasons other than primary production and where land values are likely to increase, rendering NGOs unable to compete in land acquisition. The Trust suggested that land acquisition may prove a better strategy for threatened ecosystems requiring complex and extensive levels of management and minimal or no use and development.

In the second step towards organizational maturity, NGOs need to recognize and bring in outside skills in areas where they may lack expertise. For example, three respondents emphasized that business/financial planners are crucial for developing a business plan. The task of filling expertise gaps can be achieved by adding NGO staff, by hiring consultants, by training and capacity building for existing staff or through strategic partnerships and alliances with organizations having the requisite skills and experience. Two different circumstances that NGOs deal with illustrate the importance of the latter strategy. The first is in land identification. NGOs can identify important sites for conservation using some form of conservation planning methodology or in an opportunistic, ad hoc fashion. Our exploratory analysis found that the establishment of private nature reserves by NGOs in African and Latin American countries is often highly opportunistic, whereas Australian and USA NGOs typically evince strategic land identification and acquisition strategies. For example, in the USA, TNC uses Conservation by Design, a science-based systematic approach that determines where the organization will work, what to conserve, what strategies to use and how effective they have been (see also TNC, 2006a). Four TNC respondents highlighted that Conservation by Design is typically conducted in cooperation with many other stakeholders, and one respondent noted how the organization 'became successful' when conservation planning was undertaken cooperatively, stressing the unnecessary duplication in conservation planning efforts worldwide (see Green et al. 2009 for more details on Conservation by Design).

The second set of circumstances demonstrating the value of enhancing partnerships and alliances is the legal context for establishment of a private nature reserve. Legal frameworks strongly affect the methods and opportunities for private land conservation. Land tenure laws are important for creation of a private nature reserve: 12 respondents identified strong, clearly defined and legally enforceable property rights as desirable, as they can be a critical factor for full or partial purchase of land for conservation (see also ELI, 2003; Anderson, 2004; Meiners \& Parker, 2004; Swift et al., 2004; Armsworth et al., 2006). For example, land-use criteria embedded in tenancy laws can discourage conservation land uses in favour of revenue-generating activities. Six Australian respondents pointed out that Crown leasehold land occupies over two-thirds of all privately controlled land and frequently involves pastoral leases, which generally prescribe management activities targeted towards pastoralism. Respondents noted that the management intent of private nature reserves can conflict with lease conditions. A Latin American respondent also noted that land tenancy laws often discourage conservation land uses (see also Swift et al., 2004). Uncertainties over land title registration can further complicate the process of land transfer: one respondent noted that high insecurities of land tenure in Africa may discourage international donors from funding private conservation NGOs, in turn slowing the development of private nature reserves across the continent.

In federal countries such as the USA and Australia different legal frameworks at different levels of government (i.e. national, state and local) can complicate establishment and ongoing management of private nature reserves. Two respondents highlighted that managing regulatory opportunities and constraints require NGOs to be fully conversant with the legal frameworks in their countries of operation, prior to acquisition. Although this appears an obvious conclusion, these two respondents commented that some NGOs embark on the establishment of a private nature reserve without knowing the legislation affecting sales and management practices. At least two Australian NGOs demonstrate the value of enhancing strategic partnership 
and alliances (also recognizing their gaps in expertise) by receiving legal advice on acquisitions from legal firms on a pro-bono basis.

\section{Discussion}

\section{Maximizing long-term retention of private nature reserves}

At the proximate level success of a private nature reserve is likely to depend on funding issues. The legal and fiscal mechanisms encouraging philanthropy within countries are a significant factor in covering the high costs of land acquisition and ongoing management of private nature reserves. For instance, the USA provides support for philanthropy through tax deductions against state and federal income tax, generous capital gains tax exemptions and roll-overs, deductions for conservation covenants, concessional treatment of gifts of various financial instruments (such as annuities) and a variety of tax effective charitable trust structures (SECITAC, 2007). TNC in the USA was able to raise more than USD 1 billion from its supporters in the 2006 financial year (TNC, 2006b). Thus, NGOs could take active steps towards modifying legislative frameworks, such as lobbying for laws supporting philanthropy and changes to tax provisions, particularly in countries where this may attract individual or corporate donors.

NGOs need to give greater consideration to the specific issue of management funding. The literature and the experience of respondents suggest a number of possible strategies for income generation for private nature reserves (summarized in Table 1), although the financial sustainability of such activities requires investigation. Available government programmes and grants are typically directed towards land acquisition and not management, as occurs in Australia with the National Reserve System programme (DEWHA, 2008). This issue is not unique to private nature reserves as the establishment of new public protected areas may not be matched by equivalent funding for management (Wescott, 1995), and covenant establishment may outpace the capacity of covenanting bodies to provide stewardship services (Fitzsimons \& Carr, 2007). NGOs could advertise to relevant policy-makers the need for government to allocate a greater proportion of funds towards land management. NGOs can also attempt to promote the need for management funding more compellingly to donors. However, research is required to achieve a greater understanding of the psychology of donors to conservation, to tease out the root causes of donors' relative unwillingness to fund management compared to acquisition.

Our results show that the effectiveness of acquisitions is greater when NGOs analyse and prioritize how they can meet the obligations they assume in managing a property or easement. Thus, ultimately, the successful establishment of private nature reserves depends on the organizational maturity of the institutions managing them. Our findings suggest that NGOs could develop organizational maturity by recognizing their core business, identifying gaps in expertise and taking steps to fill those gaps. For example, because the long-term financial viability of a private nature reserve must be properly assessed, NGOs should add business/financial planners to their staff or at least train existing staff in the use of market mechanisms and financial management. Similarly, results suggest that at least some NGOs embark on the process of establishing private nature reserves without being conversant with associated legislation affecting sales and management practices. It is clearly critical that an NGO be able to source the legal expertise required for managing its operations: lawyers need to be an integral component of an NGO's staff or must be brought in as consultants or collaborators within an alliance of partners (summarized in Table 1).

The importance of forming partnerships and alliances is demonstrated particularly well in the context of selection of a reserve site. Places designated as Key Biodiversity Areas represent the most important sites for biodiversity conservation, identified nationally using simple standard criteria and that form the basis for conservation planning at landscape scales (Langhammer et al., 2007). One solution for NGOs to achieve more effective land identification consists of focusing on these Key Biodiversity Areas or national conservation priorities and work with a broad range of institutions at multiple scales to define appropriate sites.

\section{Beyond land acquisition}

From a legal standpoint (in fee-simple countries; i.e. those in which a property owner has the right to control, use and transfer the property at will) the simplest way for a conservation NGO to protect ecologically valuable land is to acquire it (French, 2004). A related strategy is pre-acquisition, in which a land trust acquires a property and then re-sells or otherwise transfers all or part to a public or private owner (Merenlender et al., 2004). One obvious advantage to this strategy is that it relieves the NGO purchasing the land of bearing the ongoing management costs (Merenlender et al., 2004). Interviews revealed that TNC as well as the Trust for Nature are increasingly adopting this trend. Thus, the long-term management costs of private nature reserves can also be favoured by institutional alliances where each partner takes on a clearly defined role for either acquisition or management.

Outright acquisition and ownership is not always a practical or efficient strategy, especially in countries with weakly developed property rights or high insecurities over land tenure or where acquisition is not legally possible (e.g. Indigenous land in Australia). It is also an inefficient 
TABle 1 Possible strategies for dealing with the funding and institutional capacity constraints that affect the long-term retention of private nature reserves.

\section{Solutions to funding constraints}

National-level context

1. Lobby for laws supporting philanthropy \& changes to tax provisions as an incentive for giving

2. Lobby government for land management funding

NGO-level context

1. Set up endowment funds

2. Advertise need for management funding to donors. Examples of possible strategies include:

- Targeted education campaigns

- Identifying the sponsor with management funding (e.g. names on vehicles, signage)

3. Collect revenue from existence values through membership contributions (TNC; Anderson, 2004)

4. Raise additional funds through providing consultancy services, contract services (e.g. removal of feral animals) \& sales of wild animals (e.g. Earth Sanctuaries Ltd; Aretino et al., 2001)

5. Cross-subsidize between sites (i.e. subsidizing more remote, less profitable reserves with revenue generated from those closer to major urban centres; Aretino et al., 2001)

6. Use the emerging voluntary carbon credit \& offset markets to provide funding for acquisition, management, or restoration of large areas

Site-level context

1. Develop revenue-generating strategies. Examples include:

- Tourism or other land use activities (e.g. sustainable versions of traditional land uses)

- Leasing the land after purchase to people interested in carrying out sustainable activities, including the former owners, attaching covenants to the lease (French, 2004)

- Issuing licenses for recreational \&/or educational use of the private nature reserve compatible with conservation objectives (French, 2004)

2. Decrease management costs through volunteers willing to donate time (e.g. build trails or guard duty) \&/or talents (e.g. develop outreach campaigns; Bush Heritage Australia; BHA, 2006)

Solutions to institutional capacity constraints

1. Achieve clarity on the institution's core business \& improve strategic planning. For example:

- Differentiate NGO plans \& finances from private nature reserve plans \& finances; ensure planning for financial sustainability of private nature reserves independent of the NGO

- Ensure clarity over land \& resource tenure \& title security

- Consider the appropriateness of specializing in acquisition, pre-acquisition or covenanting of properties (e.g. TNC, Trust for Nature)

2. Identify \& fill gaps in expertise by (a) adding NGO staff, (b) hiring consultants, (c) training \& capacity-building for existing staff, or

(d) strategic partnerships \& alliances with other organizations (e.g. implementation strategies can be informed through alliances such as the Conservation Measures Partnership (CMP, 2011), developed by international conservation NGOs to better design, manage \& measure the impacts of conservation actions).

strategy where transaction costs are high, for example where there is fragmented land ownership (Anderson, 2004). The Beyond the Boundaries programme of Bush Heritage Australia targets partnerships across multiple tenures using a variety of tools to create ecologically permeable landscapes buffering existing protected areas (Cowell, 2007), whereas other NGOs are similarly becoming involved in multi-tenure reserve networks (Fitzsimons \& Wescott, 2005). For many tropical countries forming partnerships between NGOs and local landowners is an increasingly common conservation strategy (Vermeulen \& Sheil, 2007). NGOs can bypass land ownership by involving landowners in managing properties for conservation by applying conservation covenants or easements, as the example of the Trust for Nature demonstrates. Conservation organizations have increasingly turned to easements as a cost-saving approach (Parker, 2004; King
\& Fairfax, 2005; Messer, 2006) because conservation easements typically cost less than full-fee acquisition (e.g. Main et al., 1998).

However, Czech (2002) suggested that conservation easements may be insecure in the long term and thus may be better employed in regions where they are readily observable (i.e. less vulnerable to easement violation). Parker (2004) suggests that NGOs should hold conservation easements when benefits from landowner specialization are high (e.g. where landowners specialize in farming, ranching or logging, NGOs save when the easement price is lower than the cost of acquiring the land minus the value the trust can generate from those activities) and when expected transaction costs are low (e.g. by holding easements over large parcels of agricultural land). In general, both easements and fee-title acquisition (or leasehold) are tools that supplement each other and a wide range of other 
conservation mechanisms and are not either/or strategies for land conservation.

In conclusion, we acknowledge that there are likely to be differences in the lessons we have presented between different contexts, particularly between developed and developing countries. The establishment of private nature reserves may prove easier in some countries and regions than others, depending on the different legal, social, land tenure, economic and biophysical environments that prevail. Our analysis has mainly focused on examples of the establishment of private nature reserves in the USA and Australia, where detailed information is available. Further research could usefully address the extent to which the opportunities of, and challenges for, the establishment of private nature reserves differ in other contexts, particularly those of developing countries.

\section{Acknowledgements}

LP was supported by a joint studentship from the Natural Environment Research Council and the Economic and Social Research Council, UK. All the respondents who gave up time to be interviewed are gratefully acknowledged. We thank Jim Tolisano and two anonymous referees for comments.

\section{References}

Anderson, T.L. (2004) Viewing land conservation through Coasecoloured glasses. Natural Resources Journal, 44, 361-381.

Aretino, B., Holland, P., Peterson, D. \& Schuele, M. (2001) Creating Markets for Biodiversity: A Case Study of Earth Sanctuaries Ltd. Productivity Commission Staff Research Paper. Aus-Info, Canberra, Australia.

Armsworth, P.R., Daily, G.C., Kareiva, P. \& Sanchirico, J.N. (2006) Land market feedbacks can undermine biodiversity conservation. Proceedings of the National Academy of Sciences of the USA, 103, 5403-5408.

AWC (Australian Wildlife Conservancy) (2006) Australian Wildlife Conservancy Annual Report 2006. Australian Wildlife Conservancy, Subiaco, Australia.

BHA (Bush Heritage Australia) (2006) Buying Back the Bush: Annual Report 2005-2006. Bush Heritage Australia, Melbourne, Australia.

Brandon, K. (1996) Ecotourism and Conservation: A Review of Key Issues. Environment Department Paper No. 033. The World Bank, Washington, DC, USA.

Campbell, M.C. \& Salus, D.A. (2003) Community and conservation land trusts as unlikely partners? The case of Troy Gardens, Madison, Wisconsin. Land Use Policy, 20, 169-180.

Carter, E., Adams, W.A. \& Hutton, J. (2008) Private protected areas: management regimes, tenure arrangements and protected area categorization in East Africa. Oryx, 42, 177-186.

ChACON, C.M. (2005) Fostering conservation of key priority sites and rural development in Central America: the role of private protected areas. Parks, 15(2), 39-47.

Che, D. (2006) Developing ecotourism in First World, resourcedependent areas. Geoforum, 37, 212-226.
CMP (The Conservation Measures Partnership) (2011) Http:// www.conservationmeasures.org/ [accessed 11 February 2011].

Cowell, S. (2007) What do you do when the biodiversity you bought gets up and leaves? Challenges facing protected area planning for the private land trust sector due to climate change. In Protected Areas: Buffering Nature Against Climate Change. Proceedings of a WWF and IUCN World Commission on Protected Areas Symposium, 18-19 June 2007, Canberra (eds M. Taylor \& P. Figgis), pp. 112-116. WWF Australia, Sydney, Australia.

Cowell, S. \& Williams, C. (2006) Conservation through buyerdiversity: a key role for not-for-profit land-holding organizations in Australia. Ecological Management and Restoration, 7 , 5-20.

CZeCH, B. (2002) A transdisciplinary approach to conservation land acquisition. Conservation Biology, 16, 1488-1497.

DEWHA (Department of the Environment, Water, Heritage and THE ARTS) (2008) Applying for Funding for the National Reserve System. Department of the Environment, Water, Heritage and the Arts, Canberra, Australia. Http://www.environment.gov.au/parks/ nrs/getting-involved/funding.html [accessed 8 April 2008].

ELI (ENVironmental LaW Institute) (2003) Legal Tools and Incentives for Private Lands in Latin America: Building Models for Success. Environmental Law Institute, Washington, DC, USA. Http:// www.elistore.org/reports_detail.asp? $I D=10914$ [accessed 5 January 2007].

ESL (Earth Sanctuaries Ltd) (200o) Conservation Company Seeks ASX Listing. Earth Sanctuaries Ltd press release, 31 January, Adelaide, South Australia.

Figgis, P., Humann, D. \& Looker, M. (2005) Conservation on private land in Australia. Parks, 15(2), 19-29.

Fitzsimons, J. \& CARR, B. (2007) Evaluation of the Effectiveness of Conservation Covenanting Programs in Delivering Biodiversity Conservation Outcomes. Report for the Australian Government's Department of Environment and Water Resources. Bush Heritage Australia, Melbourne, Australia.

Fitzsimons, J. \& Wescott, G. (2002) Policy implications of the transfer of ownership of Scotia Sanctuary for the National Reserve System in Australia. Environmental and Planning Law Journal, 19, 329-332.

Fitzsimons, J.A. \& Wescott, G. (2005) History and attributes of selected Australian multi-tenure reserve networks. Australian Geographer, 36, 75-93.

Fоті, P.E. \& Jасов , H.M. (1989) Private public-interest land use planning: land trusts in the upper mid-west. Journal of Soil and Water Conservation, 44, 317-319.

FrENCH, S.F. (2004) What's a poor land trust to do? Alternatives for dealing with an opportunistic world. Natural Resources Journal, 44, 563-572.

Gössling, S. (1999) Ecotourism: a means to safeguard biodiversity and ecosystem functions? Ecological Economics, 29, 303-320.

Green, A., Smith, S.E., Lipsett-Moore, G., Groves, C., Peterson, N., Sheppard, S. et al. (2009) Designing a resilient network of marine protected areas for Kimbe Bay, Papua New Guinea. Oryx, 43, 488-498.

Kendall, R. (2007) The great bush buyback. Ethical Investor, 67, $25-28$.

King, M.A. \& FAirfax, S.K. (2005) Beyond bucks and acres: land acquisition and water. Texas Law Review, 83, 1941-1984.

Kitchin, R. \& Tate, N.J. (1999) Conducting Research in Human Geography: Theory, Methodology and Practice. Prentice Hall, Harlow, UK.

KRUGER, O. (2005) The role of ecotourism in conservation: panacea or Pandora's box? Biodiversity and Conservation, 14, 579-600. 
LAnghammer, P.F., BaKarR, M.I., Bennun, L.A., Brooks, T.M., Clay, R.P., Darwall, W. et al. (2007) Identification and Gap Analysis of Key Biodiversity Areas: Targets for Comprehensive Protected Area Systems. IUCN, Gland, Switzerland.

Main, M.B., Roka, F.M. \& Noss, R.F. (1998) Evaluating costs of conservation. Conservation Biology, 14, 1262-1272.

Meiners, R.E. \& Parker, D.P. (2004) Legal and economic issues in private land conservation. Natural Resources Journal, 44, 353360 .

Merenlender, A.M., Huntsinger, L., Guthey, G. \& Fairfax, S.K. (2004) Land trusts and conservation easements: who is conserving what for whom? Conservation Biology, 18, 65-75.

Messer, K.D. (2006) The conservation benefits of cost-effective land acquisition: a case study in Maryland. Journal of Environmental Management, 79, 305-315.

PARKER, D.P. (2004) Land trusts and the choice to conserve land with full ownership or conservation easements. Natural Resources Journal, 44, 483-518.

Pasquini, L., Cowling, R.M., Twyman, C. \& Wainwright, J. (2010) Devising appropriate policies and instruments in support of private conservation areas: lessons learnt from the Klein Karoo, South Africa. Conservation Biology, 24, 470-478.

Russell-French, A. (2005) The president writes. Wingspan, 15, 4. SECiTAC (Senate Environment, Communications, Information Technology and the Arts Committee) (2007) Conserving Australia: Australia's National Parks, Conservation Reserves and Marine Protected Areas. Senate Environment, Communications, Information Technology and the Arts Committee, Canberra, Australia.

Swift, B., Arias, V., Bass, S., Chacon, C.M., Cortes, A., Gutierrez, M. et al. (2004) Private lands conservation in Latin America: the need for enhanced legal tools and incentives. Journal of Environmental Law and Litigation, 19, 85-140.
Sydee, J. \& Beder, S. (2006) The right way to go? Earth Sanctuaries and market-based conservation. Capitalism Nature Socialism, 17, $83-98$.

TNC (The Nature Conservancy) (2006a) Conservation by Design: A Strategic Framework for Mission Success. The Nature Conservancy, Arlington, USA. Http://www.nature.org/aboutus/ howwework/cbd/science/art19228.html [accessed 21 May 2007].

TNC (The Nature Conservancy) (2006b) Global Reach, Local Results. Annual Report 2006. The Nature Conservancy, Arlington, USA. Http://www.nature.org/aboutus/annualreport/ [accessed 16 May 2007].

Vermeulen, S. \& Sheil, D. (2007) Partnerships for tropical conservation. Oryx, 41, 434-440.

Wescott, G. (1995) Victoria's national park system: can the transition from quantity of parks to quality of management be successful? Australian Journal of Environmental Management, 2, $210-223$.

\section{Biographical sketches}

Lorena PASQUini researches the social and policy dimensions of biodiversity conservation, especially related to land use and land management. JAMES Fitzsimons researches and works on the policy and implementation of mechanisms to achieve biodiversity conservation on public and private lands in Australia. STUART Cowell has extensive experience in forming and implementing innovative partnerships for private land conservation in Australia. KATRINA BRANDON has worked on the human dimensions of biodiversity conservation, especially poverty and protected areas, for more than 30 years. GeOfF Wescott's interests are in the areas of marine, coastal and protected area policy, planning and management. 